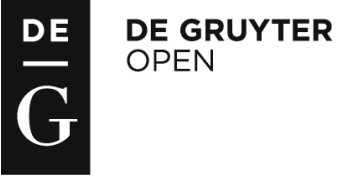

\title{
AN ALTERNATIVE PERIODIZATION OF ROMANIAN HISTORY. A RESEARCH AGENDA
}

\author{
FLORIN POENARU1
}

\begin{abstract}
In this paper, I suggest an alternative form of periodization of Romanian history. My aim is not to move around historical posts; rather I propose a different way of understanding Romanian history as such. This is the research agenda. I seek to write a world history from the perspective of a peripheral place like Romania has been. Therefore, this is not simply an attempt to insert a local, neglected, silenced or distorted history into a wider, European, global story (that is, to discover the history of "people without history"), just as it is not another attempt to "provincialize Europe" in favour of a view from its repressed margins. Instead, following Coronil (2004), I believe it is indispensable to globalize the periphery, to understand its worldwide formation. My investigation draws upon the conceptual toolkit of world-system theory and its underlining philosophy of history (Wallerstein, 2011). In the same vein, the guiding principles of my periodization elaborate on Andre Gunder Frank's insight that the exchange (or rather direct transfer) of surplus between societies is what links regions and societies as whole (Frank, 1978). The focus then shifts from a given society/state and its internal relations to the wider world-system, or world-economy, in which it is embedded. The unit of analysis is not a geographical location, but relations and networks and their historical development.
\end{abstract}

Keywords: historical periodization, world-system theories, world-economy, Romanian history

\section{Introduction}

In this paper, I suggest an alternative form of periodization of Romanian history. My aim is not to move around historical posts; rather I propose a different way of understanding Romanian history as such. This is the research agenda. I seek to write a world history from the perspective of a peripheral place like Romania has been. Therefore, this is not simply an attempt to insert a local, neglected, silenced or distorted history into a wider, European, global story (that is,

\footnotetext{
${ }^{1}$ Postdoctoral Fellow at the Central European University Budapest, e-mail: poenaru.florin@gmail.com.
} 
to discover the history of "people without history"), just as it is not another attempt to "provincialize Europe" in favour of a view from its repressed margins. Instead, following Fernando Coronil (2004), I believe it is indispensable to globalize the periphery, to understand its worldwide formation.

Moreover, this perspective does not only change the way we understand the history of the periphery, by recognizing its embedding in larger structures and wider processes, global in nature. It also challenges the way we understand global history as such. By shifting the focus of global history from the centre to the periphery we get a more acute sense of how global processes nest into and subsequently shape local processes.

By invoking the relationship between centre and periphery, it is immediately clear that my investigation draws upon the conceptual toolkit of world-system theory and its underlining philosophy of history (Wallerstein, 2011). In the same vein, the guiding principles of my periodization elaborate on Andre Gunder Frank's insight that the exchange (or rather direct transfer) of surplus between societies is what links regions and societies as whole (Frank, 1978). The focus then shifts from a given society/state and its internal relations to the wider world-system, or world-economy, in which it is embedded. The unit of analysis is not a geographical location but relations and networks and their historical development.

It has been argued that this theoretical perspective privileges trade over other key social processes, such as the organization of production and its inherent internal class antagonisms (Brenner, 1977). I leave aside these issues in this paper in order to note that without disregarding either relations of production or class antagonism (but highlighting them when necessary), I organize my periodization around modes of accumulation and surplus extraction. This enables not only a different view of periodization, but also a different problematization of Romanian history.

A new periodization emerges as a dialogue, inevitably polemical, with previous ones, which are, of course, diverse and divergent, imbued by their scholarly and ideological presuppositions and indelibly marked by the historical and political background of their production. In very broad strokes, in the first section of this paper I discuss the main frameworks of periodization of the Romanian history. I also highlight the main points of contention that shaped historiographical debates in the past two centuries. On this background, in the second section, I insert my own periodization, and the reasons for it. The final section traces the historical and theoretical sources of the periodization of world history in use today. I believe such a discussion is necessary in order to pinpoint the fact that periodization is in fact a process of theoretical and conceptual elaboration. 


\section{Frameworks of Romanian periodization}

Scoala Ardeleană [ad literam: The Transylvanian School], the school of thought developed by Romanian intellectuals in late- $18^{\text {th }}$ century Transylvania, inaugurated the modern practice of writing the history of the nation. It emphasized the Latin legacy of the Romanians and linked the local historical developments with the history of Rome. Historians of this school began their histories in 753 B.C.E. when Rome was founded. Historical time was divided by three key moments: the formation of Rome, the Fall of Rome (476 C.E.) and the Fall of Constantinople (1453). The history of Romania was inserted within this background having as key elements the formation of the Romanian people after the Roman conquest.

The periodization used by Şcoala Ardeleană was still very much entrenched in Christian categories. The national element was invoked only in relation to the legacy of Rome. This perspective shifted entirely once the Romantic national historiography that emerged after 1850s became dominant, and especially after the unification of the Romanian provinces in 1859 . Historians, now very much imbued with a sense of mission of building the state and the nation, placed the nation at the centre of the historical narrative. The origins of the Romanian states and their development towards the moment of unification became the main preoccupations of the historians. In addition, the Roman element was displaced in favor of the Dacian legacy. The history of Dacia that predated the Roman invasion and the foundation of Rome became legitimate topics of historiographical research. The origins of the Romanian people were pushed back in time. This introduced a new period in historiography, the very ancient one. With very few exceptions, all histories of Romania began sometimes around 5000 - 3000 B.C.E.

By the end of the $19^{\text {th }}$ century some of the key dates and elements of periodization that will become pivotal in the historiography of Romania were already in place. The moment 1821 (the rebellion led by Tudor Vladimirescu) and 1829 (Adrianople peace treaty) signified the turn towards modernity for Romanian principalities. Michael the Brave reign and short-lived unification in 1600 was inscribed as a key date and an important period. The fight for independence against the Ottoman Empire epitomized the main thread of the historical narrative. The fall of Constantinople retained an important significance, but at the same time history became more focused on the formation and consolidation of the Romanian principalities and their major victories against the Ottomans. For many historians (including Nicolae Iorga) periodization was marked by the succession of local kings and their families. This type of periodization also enabled the "discovery" of a sui generis Phanariot period in the $18^{\text {th }}$ century. 
The enlargement of 1918 and especially the annexation of Transylvania altered the historiographical narrative and periodization during the interwar period in significant ways. For historians it became of paramount importance to consolidate and justify the 1918 moment. Already a field imbued with nationalism, history writing moved even more in that direction after Transylvania and Bessarabia became parts of the national story. Questions of origins and language were more important than periodization. Despite the awareness that 1918 was a historical threshold, increasingly the period from 1866 to 1914 the rule of Carol I - was enshrined as a distinct one. For many later historians (including Keith Hitchins, 2013), 1866 remained a key date separating two distinct periods.

An alternative historical periodization was developed in the interwar period by the textbook of R. David (quoted in Rusu, 2013). David identified five periods: 1) the formation of the Romanian people (from 515 B.C.E, the moment of Darius invasion, to 1241, the Mongol invasion); 2) the formation of the Romanian states (1241-1386); 3) the Romanian people and states in the epoch of rising Ottoman power (1386-1711); 4) the epoch of Ottoman decline (1711-1856), and 5) the formation of the national state (1856-1930). Several elements catch the eye of this periodization. First, the history of Romanian territories is directly linked with the ascension and fall of the Ottoman Empire, thus inscribing their history within a wider structure. Secondly, 1821, 1859 (the unification of the Principalities), 1866 (the enthroning of Carol) and 1918 (the formation of Greater Romania) - key dates for other historians - are absent here. Thirdly, the state is at the centre of historical periodization, not kings or other social actors.

David's periodization was quite unusual for his time when the historical consensus was different. By and large, the history of Romania was divided along these lines: 1) the formation of the people and the state (from the earliest of times until around 1300s); 2) the consolidation and heroic moment of the Romanian states (1386, the beginning of Mircea the Elder's rule and 1504, the end of Stephen's the Great rule in Moldavia); 3) the Ottoman dominance that stretched until 1821, with the important sub-period marked by the Phanariot rule, and 4) the modern times inaugurated by 1821/1829 moment.

Marxist historians shared some of the key elements of this consensus. Their periodization derived from Marx and was based on the modes of production that defined the epochs (primitive communism, slavery, feudalism, capitalism and communism). For them the challenge was to identify when these epochs began and finished. For example, for Lucrețiu Pătrășcanu (1969) feudalism began with the formation of the Romanian states in 1300s and ended in 1746-1749 with the abolition of serfdom. What came after was a period defined by the interests of the local landed aristocracy that sought to capitalize on the opportunities offered 
by the global market. Indentured labour was meant to extract more labor from the peasants in order to produce grains for export. For Pătrășcanu this process accelerated after the peace treaty signed in Adrianople in 1829, though it was already in place by the beginning of the 19th century. Therefore, for Pătrășcanu, a full capitalist-bourgeois revolution was still needed as late as 1945 in order to erase for good the influence of the landed classes.

Pătrășcanu was in an indirect dialogue with a fellow Marxist (DobrogeanuGherea) and with the bourgeois historians of the time (such as Nicolae Iorga and Radu Rosetti). For Gherea, the emergence of feudalism in Romania was the outcome of the country's insertion within capitalism. According to him, this took place after the Adrianople treaty, but more forcefully so after the 1860s. Neoserfdom was the embodiment of this relation. Henri H. Stahl, about half a century later, took Gherea's idea on board but moved the dates backwards. For Stahl, Romanian feudalism was indeed an outcome of capitalism, but this process began sometimes in the seventeen century. At the other end, for Iorga there was no feudalism in the Romanian principalities to speak of, at least one bearing the marks of the traditional western one.

This incipient debate about feudalism that will resurface in the postwar period both in the West and in Romania was curtailed after 1945/1948 with the emergence of Romanian People's Republic - that is, the ensuing of state socialism. State socialism altered all spheres of life, including history writing and historical periodization. Mihail Roller's textbook became the norm of the 1950s and its periodization was based on the five Marxist stages. Primitive communism and slavery overlapped in Dacia until the retreat of the Romans south of the Danube in 271 C.E. This marked the beginning of feudalism that lasted until 1821. From 1821 to 1944 was the period of Romanian capitalism, followed, after 23 august 1944, by communism. What needs to be noted here is that despite its radical remaking of the periodization and of the historical interpretation of the Romanian history, Roller was also beginning his history in Dacia and maintained 1821 as the date when modernity ensued.

Following Roller's downfall the historians kept, by and large, the same periodization and maintained the idea of a Romanian feudalism stretching to sometimes between the 1750s and 1820s (that is, between the abolition of serfdom and Adrianople peace treaty). The dates varied according to one's research interest. For those with an eye to labour relations, the abolition of serfdom was the crucial moment. For those more inclined to look at trade, 1774 (the peace treaty of Küçük Kaynarca) or 1829 (Adrianople) became more important dates in the transition from feudalism to capitalism.

Daniel Chirot (1976), working in the vein of world-system theory, designed a sui generis periodization: 1) the formation of the Romanian states and the dominance of collective property of land (1250-1500); 2 ) the rise of the 
seigniorial state and the consolidation of the boyar class (1500-1600); 3 ) the protocolonial political economy (1600-1821); 4) the transition to the colonial political economy (1821-1864), and 5) the development of the colonial political economy and the agrarian crisis (1864-1917). Chirot established his periodization at the intersection between modes of production, modes of ownership, state forms and colonial relations. This resulted in the eclectic tableau presented above. It alternates between longer periods (1600-1821) and very short ones (1821-1864), which ultimately deems the model quite untenable.

The later stages of state socialism brought about an increased nationalization of the historical discourse and also subtle changes. The Marxist-inspired historical periodization was still nominally in place. Historians, however, gradually developed a different language. Primitive communism and slavery were replaced by ancient history. Feudalism became the Middle Ages. Late $18^{\text {th }}$ century and early $19^{\text {th }}$ century became early modernity, while the period after 1848 until 1944 was considered to be the modern period. 1944 inaugurated the contemporary epoch. This change was not accidental, but it reflected a move away from Marxism towards bourgeois and national categories, sometimes directly borrowed from the interwar scholarship.

This trend that begun before 1989 continued afterwards and introduced a new form of historical periodization. Today, the mainstream historical narrative operates with the following periodization. The starting point of Romanian history is located sometimes around 2500 B.C.E with Burebista (if not earlier for some historians). This ancient period stretches until 271 C.E. when the Romans moved south of the Danube. The millennium that followed (until the Mongol invasion of 1240s) is usually glossed over because of lack of solid sources but it is nonetheless characterized by a series of violent invasions. For some historians (see Georgescu, 1992) this was the period of local feudalism.

This dark period was followed by the luminous moment of the formation of the Romanian states in the 14th century. Up until the ensuing of the Phanariot period at the beginning of the 18th century, this 4-century period is usually subdivided according to key kings, especially Mircea the Eldest, Vlad Țepes, Stephen the Great and Michael the Brave and their battles with the Turks. Constantin Brâncoveanu and Dimitrie Cantemir constitute new additions to this gallery of important figures.

Traditionally, the Phanariot period has been seen as a dark one, the moment of direct, brutal Ottoman exploitation. For some historians, however, this period also nested the seeds of modernity (Georgescu, 1992; Hitchins, 2013).

There is a well-established consensus that modernity ensues sometime between 1821/1829, even though some historians suggest the 1740s (the abolition of serfdom). Whatever the precise origins, there is a wider agreement that 1944 
represents the end-point of this modern period. Communism inaugurated a new dark age and 1989 brought the country back to a "normal” path of development. Communism has also been subdivided, most commonly into three periods: 1 ) the Stalinist early period (1944/1948-1964); 2) "the thaw" period (19641971), and 3) the dictatorship of Ceausescu (1971-1989).

On this background of evolving and overlapping forms of historical periodization in the next section I propose a different one and the reasons for it.

\section{An alternative periodization of Romanian history}

\section{The formation and consolidation of the Romanian principalities (1240-1500)}

The Mongolian invasion curtailed the eastern expansion of Hungary and pushed the declining Second Bulgarian Empire south of the Danube. The retreat of Mongols following the invasion, not before imposing practices of extracting tribute, emboldened the local chieftains and military rulers - usually the intermediaries through which the tribute was collected - to exert their own influence and to keep the tribute for themselves. With the Mongols in retreat, Hungary also made claims for the territories east of the Carpathians and this brought the Crown and the local populations into conflict. However, the Crown was unable to occupy militarily the territories and by 1300 local chieftains refused to pay tribute to the Crown. This was also the case with Basarab, a ruler descending from a family of contentious warrior clan. As a result, the Hungarians invaded the country in 1330. Basarab emerged the unlikely winner and as a result crowned himself as the new king of Wallachia.

The formation of Moldavia was even more the result of struggles for monopolizing the tribute. The rebellion of the local rulers against the representatives of the Hungarian crown (stationed there as a form of defence against the Tatars and the Poles) enabled Bogdan to crown himself king in 1359.

The formation of the two principalities was strongly connected to another outcome of the Mongolian retreat to the North of the Black Sea. There they offered Venetian merchants the possibility to conduct trade on the Black Sea to the benefit of the Hoard. This led to the establishment of two important trade routes: 1) from the Black Sea to the Danube and then on land to Hungary; 2) through the Danube Delta and then up north through what is now the South of Bessarabia and all the way up to Poland. Both Romanian principalities emerged as attempts to tax the trade going through these routes. A century after their formation (for Moldavia in fact until the early 1500s) this constituted the main source of revenue for the Romanian states. 
The social structure of the newly formed states was quite simple: free peasants living off collective land. They were pastoralists and lived mainly in the mountains and in the hills. They had to pay tribute as communities to the military rulers and then to the state representatives, but the amount was small and did not generate changes in the mode of production or accumulation.

\section{Tribute towards the Porte and the formation of the local land-owning class (1500-1700)}

The Ottomans struck Constantinopole for the first time (1356), as the Romanian principalities were in the process of formation. By 1459 much of the Balkan Peninsula was conquered and by 1479 Albania too. More significantly, strategically and symbolically, in 1453 Constantinople fell. In 1476 the Ottomans entered both Wallachia and Moldavia (after previous incursions north of the Black Sea) and obliged both states to pay tribute.

Concomitantly, the Ottomans engaged in warfare in the Mediterranean with Venice (1463-1503). This pushed out the Venetians from the Black Sea, which fell entirely under Ottoman control. As an outcome, the trade routes that the Romanian states taxed were disrupted and subsequently the revenues were dramatically reduced. With the tribute rising, the fiscal crisis of the states was inevitable. The states were thus forced to turn inward in order to generate funds.

The need for cash created a tension between the kings and the class of nobles/boyars. This was a class in the process of consolidation, which initially emerged out of fighting wars and collecting tribute. Faced with the prospect of dwindling revenues due to the requirements of the Porte, the boyars sought to weaken the central authority of kings in order to keep the largest part of the revenues for them. This aligned their interests with those of the Porte against the kings and in favour of extracting more surpluses from the local populations.

Hence, increasingly after the 1550s, when trade became largely oriented towards the south and skewed in favour of the Ottomans, the boyars began to acquire not land as such, but villages. While the land theoretically remained communal (or at least the parts of it that were not bought by the boyars), villages and villagers could be bought and sold by the boyars. Such villages became un-free. They could gain their freedom only by paying a sum of money to the boyar or by offering products in exchange (usually a number of horses, which point again to the pastoralist nature of the agriculture).

However, population deficit, the persistence of pastoralism and the existence of unused land (or the possibility to expand lands through deforestation) made the process of village acquisition a tenuous one and allowed villagers significant space of manoeuvre and meaningful strategies of resistance to boyars' encroachment. 
In 1600 Michael the Brave, a former merchant and the biggest single owner of villages at the time, attempted to unite the three Romanian provinces in one state, independent from the Ottomans. This was a premature attempt of the local boyar class to territorialize its power into an independent state. The project failed, but for the next 100 years, just as the boyars were acquiring more wealth and the Ottoman tribute was growing harsher, the boyars continued to harbour the same dream. Constantin Brâncoveanu was the perfect example of this confluence. A high boyar, his family was one of the wealthiest in the region. As king he sought to disengage Wallachia from the Porte in order to avoid paying tribute and thus to safeguard his (and his family) immense fortunes. Similarly, in Moldavia, Dimitrie Cantemir - also from a wealthy boyar family - sought to align the principality with the interests of the emerging Russian Empire, Europeoriented under the leadership of Peter the Great. Brâncoveanu was beheaded in Constantinople and Cantemir was forced to flee when the Russian troops were defeated in the 1711 Russian-Turkish war.

The boyars sought to consolidate their class interests within the state and to align the countries with European interests in order to get rid of the Ottoman tribute. This was in keeping with a wider European transformation: the formation of the modern interstate-system following the peace treaty of Westphalia in 1648. The Romanian boyars sought to join this revolution, but failed, largely due to their overall weak class position and the absence of Romanian principalities from the consolidating capitalist world-system.

Meanwhile, the Ottomans were defeated in their last surge on Vienna (1683) and thus their European expansion blocked. They began retreating from Central Europe in favour of the Habsburgs. The 1711 war with Russia was the signal moment of Russia's western and southern expansion, at the expense of Ottoman's presence in the regions surrounding the Black Sea. This was the confluence that brought the Phanariot class to power in the Romanian principalities.

\section{Imperial domination (1711-1859)}

The Phanariot ruling in the Romanian principalities generated class struggle between them and the local boyars. The Phanariots were vehicles of extracting even more wealth at the expense of the local classes. Their goal was, however, undermined by the fact that in early $18^{\text {th }}$ century the Romanian principalities became battlefields of the wars between Russia, the Ottoman Empire and the expanding Habsburg Empire. This led to severe population shortages and the impossibility to develop crop agriculture. Pastoralism continued to dominate the economy, despite the attempts of the Habsburgs to switch to grain production during their occupation of Oltenia and Bukovina. 
Russia's southern expansion towards the Black Sea - in its quest to become a naval power and reach the Mediterranean Sea - accelerated after the 1750s. The Ottomans were faced with the increasing dominance of rapidly industrializing Britain and her dominance of trade routes in the Atlantic and increasingly in the Pacific and Middle East. Just as the Ottoman Empire was drawn into the expanding capitalist world-system after the 1750s, its hold of the Romanian principalities was severely weakened. The defeat in the 1776 war with Russia marked the de facto transfer from Ottoman to Russian and Habsburg subordination. The Russian Empire got the upper hand during and after the Napoleonian wars (in 1812 Russia annexed half of Moldavia) and reached a status akin to occupation in the 1830s.

Russia tried to organize the principalities politically and economically in order to make them producers of grain for its expanding armies. This was the role of Regulamentele Organice, the first constitutions of the Principalities. The most significant change was the expansion of corvée labor, already in place in the second half of the $18^{\text {th }}$ century, which marked the transfer from pastoralism to systematic grain production. The number of mandatory days of work (claca) was increased and peasants were restricted from buying their work through money as before. Moreover, advances in the quality of grain production and the decreasing number of wars led to an unprecedented population growth. By the second half of the $19^{\text {th }}$ century labour supply in the countryside became for the first time in history in excess, which further diminished the resistance options of the peasants.

Peasants did not own the land and they had to work for the landlord in order to gain access to it. The increase in population deprived the peasants of one weapon of resistance (that of moving to areas where the labour was in short supply) and the stringencies of crop production limited the efficacy of making land available by deforestation. However, the boyars were not de jure owners of the land and they also lacked the wherewithal to efficiently mobilize peasant labour in order to extract significant surpluses.

However, at the same time, Russian imperial interests were curtailed by England. Russian expansion in the Romanian territories and then in the Balkans signalled an attempt to reach Eastern Mediterranean. This would have transformed the Russian Empire into a naval force of global capabilities, a situation England was keen to avoid. This brought England into the Crimean war (1853-1856) on the side of the Ottoman Empire and against the Russians. The unification of the Romanian states as a buffer zone and western outpost in the region emerged as a solution after the war. This solution was also favourable to the interests of the Romanian boyars who understood that they could benefit from the free trade imposed by the global hegemon. They pushed for the unification in 1859 , amid other competing political solutions in the region. 


\section{State-building and nation making (1860s -1980s)}

Alexandru Ioan Cuza, the first leader of the unified states, was a reformist. He introduced private property relations in agriculture, among other sweeping changes. While peasants become proprietors, the main beneficiaries were the land-owning boyars who became de jure owners of about $70 \%$ of the land. They were thus incentivized to rationally exploit the land in order to make profits. To do so, it was crucial to extract labour from the peasants at a low cost. The new land-owning relations helped in this respect. Peasants acquired enough land to ensure only a modicum of existence, but not more than that. Therefore, they had to seek work on boyar's land in order to compensate. The time spent working on the boyar's land constantly increased towards the First World War. The great peasant revolt of 1907 was testament to the levels of exploitation the peasants were subjected to in the new configuration.

The political and economic dominance of the landed aristocracy retarded the development of cities and industry, albeit not entirely. In the second half of the $19^{\text {th }}$ century the landed aristocracy ceased to live on their rural domains and moved into the big cities where they spent their proceeds from agriculture on real estate, industrial goods (usually imported) and cultural consumption. Moreover, the need to move the grains efficiently abroad led to the development of an important railroad network, which subsequently accelerated horizontal and vertical industrial processes, albeit on a small scale. In addition, land was exploited not only in relation to agriculture but also for its underground resources. Extracting metals, coal and oil became important sources of revenue, albeit the state had its own shares in these areas.

The dominance of the landed aristocracy was not as strong as it might appear. The global crisis of 1873-1896 led to a downturn in agricultural prices on the global markets. This in turn dwindled state revenues in a context in which the war for independence and the constant expansion of bureaucracy demanded more state income. The fiscal crisis was averted through borrowings, first from Austria and then from Germany. The creditor countries pushed for free trade agreements so that their industrial products could flow easily into the country. This double dependency on the world market solidified the need for more protectionist measures and for the development of a local industrial sector. The state bureaucracy, the segment of the boyar class that also held industrial interests and the emerging financial elite saw their class interests aligned in this direction. Politically they converged in the liberal politics of sui generis industrialization announced as early as 1905 (prin noi înșine - through ourselves).

The full implementation of this program came only after 1918, when, at the end of WWI, the local aristocracy lost its lands and its political clout. 
Land was redistributed to restless peasants. The reform bought the social peace (in the context of the 1917 Bolshevik revolution), but economically was completely inefficient. Albeit Romania gained significant territories after 1918, her agricultural output sporadically reached the pre-war levels only in late 1920s. For a while in the 1920s, Romania had to import grains and food in order to cover the internal demand.

The agricultural reforms of 1918 split the land into small plots owned by increasingly large peasant families. The size of the plot led to diminished returns, prevented the economy of scale and left the peasants without the means for technological investment. Inheritance customs further fragmented the size of the land, just like the practice of selling pieces of it during really bad times. This led to internal differentiation within the peasant class, which prevented a new 1907 moment in the interwar period. Also, the surplus of labour and the dire conditions of the countryside provided the bodies for the incipient urban industrial sector, even though commuting between the industrial and the rural sector was still common.

The cooperativization of agriculture as a solution to the crisis emerged in the 1920s and developed in the 1930s, but it was forcefully imposed top-down only after 1948 by the Communist Party, when large estates were also confiscated. By late 1980s however this mode of agricultural production was also in crisis.

While the agricultural production sank into misery and low levels of productivity for the better part of this period, certain urban and industrial areas prospered and expanded. The main actor of this process was the state. It bought the large part of the domestic industrial output and it also controlled key industrial sectors and extractive industries. Prior to 1945 this process was led by the class alliance of state bureaucrats, domestic and international industrialists and the financial bourgeoisie. After 1945, it was led by the cadres of the Communist Party. Centralization, planning (already introduced in late 1930s) and the vertical political control of production and investment accelerated the industrial development after 1945 to the extent that Romania had one of the biggest industrial growth rates in the world in the 1950s and 1960s.

When the internal sources for development were exhausted (sometimes at the end of the 1960s), the Party had to borrow on the global financial markets. The initial sheltered industrialization fuelled by the interwar legacy and the post-war soviet inputs was also reaching its limits and therefore the continuation of the industrial efforts required technological upgrades as well. Starting in the late 1950s, but increasingly so in the 1960s and 1970s, Romania opened up to the global market for technology and hard currency. This brought in patents and loans but also linked the country's economy to the fluctuations of the global market. The second oil crisis of 1979 and the overall neoliberal 
policies it signaled brought to an end the era of cheap money. Borrowing countries like Romania entered fiscal crisis and became insolvable. This marked the end of the developmentalist ambitions, best embodied by the end of the expanding industrial program in the early 1980s.

\section{The neoliberal peripheralization (1980s - 2009)}

More than 1989, the austerity politics of the second half of the 1980s brought to an end the developmentalist goals of the 20th century and with them of the communist party itself. The industrial program, both before and after 1945, was seen as an imperative in order to catch-up with the developed West. Communism never contradicted this presupposition; it only offered a different political form for organizing this effort. This aspiration started to wane in late 1980s and completely disappeared afterwards.

After 1989, paradoxically, just as the mainstream discourse was claiming the return to Europe, in practice the country was sliding towards a new form of peripherialization, similar to that of the 1830s. The gap was widening, not narrowing. Export-oriented economy of raw materials, low-skilled production based on cheap labour, and immigration became the main features of the new economy. The former bureaucrats and technocrats drove this process to their own benefit and managed to control the key political functions of the state. While the social functions of the state were weakened (and its entire legitimacy as a social actor), its repressive institutions were enhanced. The neoliberal ideology became the norm and its main function was to normalize and justify the rapidly increasing internal differentiations brought about by the "structural adjustments".

EU accession meant integration into a German-dominated, hierarchically organized European market, while NATO membership reaffirmed the geopolitical role of the country at the margin of the US Empire (just like in the 1830s). These processes led to the formation of distinct segments of class. Their interests were aligned with those of the international structures and sought political representation against the monopoly of the ex-communist bureaucrats. The crisis of 2009 first deepened these features, but the long-term outcome is yet to be configured.

\section{Theory and history of historical periodization}

I believe that the periodization of Romanian history I proposed above has certain merits. First, each period brackets a certain longue durée historical process. Thus, periods reflect larger trends rather than paying homage to certain key events or dates. Secondly, I renounce the practice of labelling epochs either by 
the nature of historical time (Middle Ages, modern, contemporary etc.) or by the nature of the mode of production (feudalism, capitalism). Rather, what becomes important is the nature of social processes in their context. From this perspective, for example, it is quite irrelevant whether Constantin Brâncoveanu was an early modern leader or an early capitalist. Important are the social mechanisms that made possible the accumulation of his huge wealth. As such, thirdly, this periodization recognizes the fact that major transitions cannot be expressed by clear dates. Therefore, it makes no sense to identify the emergence of capitalism in Romania in 1776 or 1829 . Consequently, this type of periodization rests on theoretical and methodological assumptions about historical time and social transformation.

In this section, I expand on this point in order to highlight the theoretical role of periodization for history writing and to underscore some of the main tenets of historical periodization as they developed in the process of periodizing European history.

Historical periods are intellectual abstractions. Periodization is, therefore, a matter of historical theory, which makes it the fulcrum of the politics of writing history. There is no neutral way of periodizing history, just as it is impossible to write history without sequencing it first. What appears to be a simple matter of convention, a tool in the toolkit of the historian, periodization represents in fact the apriori of historical investigation. It is the unstated ideological background that guides the formation of historical knowledge and research. The process by which the historian carves out historical periods also presupposes a very clear dialectics: that between continuity and change. Historical periods are characterized by long-term continuities, internal homogeneity and recognizable substantial features that allow the historian to retrospectively identify a period as such. Similarly, the historian needs a theory of social change in order to be able to identify transitions, the dissolution of the old relations and the birth of a new period or epoch.

Religious, that is, Christian concepts of historical time guided the understanding of history up until the $14^{\text {th }}$ century. In this account, sacred and secular time coexisted, denoting two interlinked histories. The classical formulation of these imbrications was the work of St. Augustine. The sacred history was derived from the Bible and had as its starting point the Creation and its ending point the Second Coming. Between these two landmarks, major events (such as the Great Flood, Christ's resurrection and so on) separated distinct epochs (Green, 1992).

On the background of this divine history, the secular history of kings and events took place. After the Christianization of the Roman Empire, the Fall of Rome in 476 became a crucial moment in the history of Christianity. 
Historians in the Holy Roman Empire sought to magnify the importance of this historical event. They presented the Empire as the de facto successor of Rome and the embodiment of Christianity against barbarity.

This triumphalist narrative was first contested by the Italian poet Petrarch in 1330 who coined the phrase Dark Ages to refer to the period between the fall of Rome and the year around 1000. A century later, in 1439, the Italian historian Flavio Biondi used for the first time the well-known phrase the Middle Ages. For Petrarch, Biondi and other Italian humanists, the fall of Rome put an end to the classical civilizations of Antiquity. What followed was a period of darkness and barbarity, a discontinuity. The Renaissance movement was supposed to revive the legacy of the classical civilization, to bring it to life again in a new context. In 1860 Jacob Burckhardt explicitly identified the return to classical antiquity by the Italian Renaissance as the moment of birth of modernity. However, this awareness was absent in $14^{\text {th }}$ century for the humanists: rather than looking forward to the future, they were looking backwards to the splendour of classical civilizations.

The reaction of the Italian humanists coincided with the ascension and then the decline of the Italian republics from the late $13^{\text {th }}$ to $15^{\text {th }}$ centuries in world trade and finance (Arrighi, 2010) and it was directed against their northern rivals, the German-based Holy Roman Empire. It was an ideological movement that emerged at the end of the Guelph-Ghibelline wars (about 1330s) and reached its nadir during the prolonged Italian wars at the end of the $15^{\text {th }}$ century.

Similarly, the Lutheran Reformation was a reaction rooted in the political economy of the $16^{\text {th }}$ century Europe where Habsburg Catholic Spain, financed by the Italian city-states, was seeking the formation of a European empire. On the terrain of history, the Reformation agreed with the Italians that the fall of Rome inaugurated a Dark Ages. However, for them the main culprit was not German leadership, but papal corruption. Catholicism as such was identified with the Dark Ages and the solution was a return to more religious piety. Luther and his followers explicitly re-affirmed the presence of God in history and considered the task of the historians that of making this presence explicit. While the Reformation ran counter to the main tenets of the Renaissance, it also posited the existence of two distinct epochs: before and after the fall of Rome.

This dualist understanding of history started to gain ground after the end of the Thirty-Years' War in 1648 when Catholicism was defeated and with it its pretences to continuity. In addition, the establishment of the international system of states following the peace treaties of Westphalia strengthened the central authority of the monarchs. Their actions, deeds and historical accomplishments became the subject matter of history and the focal points of historical periodization (by reigns and heirs). 
The religious history was rapidly losing ground in this context. Moreover, the history was firmly divided between an ancient past (before the fall of Rome) and a modern period stretching into the present, with no other major discontinuities. This was reflected for example by the institutionalization of history in the universities of Oxford and Cambridge in 1720s when the Chair of Modern history dealt with everything that happened after the fall of Rome. Bernard Lewis noted wryly the absurdity of this situation today when the departments of Modern History in Oxford and Cambridge deal in fact with what other departments consider being, without a doubt, Medieval History (Lewis, 2009).

Meanwhile, however, the tripartite system that is now widely in use was slowly making its inroads into European consciousness as well. Cellerius, a German philologist, offered the first clear formulation in late $17^{\text {th }}$ century when he explicitly identified a "middle history" between the ancient and modern periods. For Cellerius, 1500 marked the threshold between the middle segment and the modern period (Green, 1992). According to Reinhart Koselleck, the concept of Middle Ages became accepted only in the $18^{\text {th }}$ century when it still retained a pejorative meaning. In the $19^{\text {th }}$ century it became a definitive historical period (Koselleck, 2002).

The Enlightenment played a crucial part in this transformation. Immanuel Kant was one of the first to object to the manner in which history was arranged according to pre-given (religious) chronology. He advocated for historically immanent temporal criteria. For Koselleck, this was the saecula, or the Jahrhunderte (Koselleck, 2002). The century (which etymologically bears the mark of secularism) became the new criteria for historical periodization and unit of analysis from the $18^{\text {th }}$ century onwards. The invention of this unit the century - accelerated the tendency towards historical periodization and fragmentation even more, thus enabling the discovery of a "century of Enlightenment" for example and, more generally, of the modern age as such.

The sweeping economic, social and political transformations inaugurated by the Industrial and French Revolutions cemented the belief by mid-19 th century that this was a distinct, new and substantially different period in the history of mankind. The existence of the historical period imposed itself on the historians and their task became that of tracing the exact moment of its emergence. I mentioned above that Burckhardt by 1860s in Switzerland, but also Michelet about the same time in France, identified the Renaissance as the precursor of modernity. For Republican historians, the French Revolution prefigured by the Enlightenment was the undisputable moment of rupture. In England, the industrial revolution beginning in the 1750s and the transformations it brought in production was the key moment. 
There was no dispute by this time about the tripartite division of history: ancient, medieval (middle) and modern. The only question was that of setting the boundaries between them right. Between the turn of the $19^{\text {th }}$ century and the ensuing of WWI, especially in British academia, the key moment of transition to modernity was identified in 1500 . This was the time of Columbus, Erasmus, Machiavelli, Copernicus and Luther as exponents of sweeping changes in all essential domains of life. During WWI, in a POW camp, Ferdinand Braudel came up with the idea of how to organize his dissertation on the history of the Mediterranean: around the reign of Philip II, thus setting his plot also around 1500s. Braudel's work became hugely influential after WWII in French historiography and in the US academia where Immanuel Wallerstein developed his world-system theory based on Braudel's insights.

The postwar period stabilized the tripartite periodization of European history, which was always stretched to cover the world history as well. Today it is still very much in place. While variations and contestations exist (most notably Frank's 5000 year macro-period), this framework is constantly reinforced by existing institutional and ideological settings of worldwide academia and the formal and informal consensus of professional historians.

The type of periodization I suggested in this paper, from the periphery and open to wider political and economic structures might be helpful also for rethinking this European-cum-global framework of periodization and its longheld assumptions. Let me end by way of an example. How to characterize the 1750s in the Romanian Principalities from the perspective of this European periodization? Depending on one's framework they were on the verge of modernity, in the Middle Ages, in feudalism or in some unspecified form of Ottoman dominance.

Even if we enlarge the framework a little, contradictions still persist. Since they were under the influence of the expanding Habsburg and Russian empires, the Principalities were peripherally participating to the early modern transformations. Seen from the perspective of the Balkan peripheries of the Ottoman Empire they appear closer to what was called Medieval Islam. The same ambiguity holds for the Ottoman Empire itself. For some historians, the 1750s represent the moment of its incorporation into the capitalist worldsystem. Others noted by contrast the strengthening of the feudal relations in the Empire's agricultural areas at the same time.

Persisting with classical categories such as ancient, middle and modern in order to characterize historical time might lead to more ambiguities than clarity. Similarly, Marxist-derived categories relating to modes of production (slavery, feudalism, capitalism, etc.) have lesser analytical value than it was once thought, especially for peripheral places like Romania that do not neatly 
fit the 5-stage model. In this paper I suggested that historical periodization and historical analysis based on relations of accumulation within broader political units offer more analytic clout for understanding historical transformations.

\section{REFERENCES}

Arrighi, G. (2010). The long twentieth century. Money, power and the origins of our time. London: Verso.

Brenner, R. (1977). The origins of capitalist development. A critique of neo-Smithian Marxism. New Left Review, I/104, pp. 25-92.

Chirot, D. (1976). Social change in a peripheral society. The creation of a Balkan colony. New York: Academic Press.

Coronil, F. (2004). Latin American postcolonial studies and global decolonization. In N. Lazarus (ed.): Postcolonial literary studies. Cambridge: Cambridge University Press, pp. 221-240.

Frank, A. G. (1978). World Accumulation (1492-1789). New York: Monthly Review Press.

Georgescu, V. (1992). Istoria Românilor [The History of Romanians]. București: Humanitas.

Green, W. A. (1992). Periodization in European and World History. Journal of World History, 3(1): 13-53.

Hitchins, K. (2013). România (1866-1944). București: Humanitas.

Koselleck, R. (2002). The practice of conceptual history. Timing history, spacing concepts. Stanford: Stanford University Press.

Lewis, B. (2009). The Periodization of history. Lecture delivered at Princeton University on 07/01/08.

http://www.gatestoneinstitute.org/323/the-periodization-of-history---excerpts [Last accessed 27.05.2016].

Pătrășcanu, L. (1969). Un veac de frământări sociale [A century of social unrest]. Bucharest: Editura Politică.

Rusu, M.S. (2013). Topografii ale trecutului: structurarea şi restructurarea conştiinţei istorice româneşti prin manualele naţionale de istorie [Topographies of the past: the structuration and restructuration of Romanian historical conscience through history handbooks]. Sociologie Românească, 9(1): 84-102.

Wallerstein, I. (2011). Historical Capitalism with Capitalist Civilization. London: Verso. 